\title{
On the Training Mode of Maritime Rights Protection and Law Enforcement Talents Under the Strategy of Maritime Power
}

\author{
Sun Cen ${ }^{1, *}$, Wang Liming ${ }^{2}$ \\ ${ }^{1}$ School of Marine Law and Humanities, Dalian Ocean University, Dalian, China \\ ${ }^{2}$ Security Department, Dalian Ocean University, Dalian, China
}

Email address:

suncen@dlou.edu.cn (Sun Cen),wlm@dlou.edu.cn (Wang Liming)

${ }^{*}$ Corresponding author

\section{To cite this article:}

Sun Cen, Wang Liming. On the Training Mode of Maritime Rights Protection and Law Enforcement Talents Under the Strategy of Maritime Power. Humanities and Social Sciences. Vol. 9, No. 1, 2021, pp. 1-6. doi: 10.11648/j.hss.20210901.11

Received: December 28, 2020; Accepted: January 11, 2021; Published: January 18, 2021

\begin{abstract}
Marine rights protection and law enforcement personnel are the main actors in the practice of maritime rights protection and law enforcement, and the quality of personnel training is directly related to China's maritime rights protection and law enforcement ability and response level. It is an important guarantee for the realization of the strategic goal of building a maritime power and a basic requirement for fulfilling the responsibilities of a great power to build a contingent of Chinese maritime rights protection and law enforcement personnel that is commensurate with China's international status and national strategic interests. The U.S. Coast Guard is the most powerful and mature maritime law enforcement force in the world, and Japan is the main country around China. Learning and understanding the experience and practice of marine rights protection and law enforcement personnel training of major maritime powers and China's major neighboring countries has important reference value for the formulation of China's marine rights protection and law enforcement personnel training strategy. On the basis of combing the relationship between the strategy of maritime power and personnel training, and the main problems faced by the personnel team of maritime rights protection and law enforcement, this paper analyzes the experience and practice of personnel training of maritime rights protection and law enforcement in the United States and Japan, and puts forward four countermeasures to strengthen the construction of personnel team of maritime rights protection and law enforcement. They are: 1) Strive to Build a Complete Training System of Marine Rights Protection and Law Enforcement Talents with "Academic Education + Professional Education"; 2) Attach Great Importance to the Cultivation of Practical Ability of Maritime Rights Protection and Law Enforcement Personnel; 3) Make Full Use of the Human Resources of the Army, Police and the People; 4) Deepening Exchanges and Cooperation to Cultivate Talents with International Vision.
\end{abstract}

Keywords: Maritime Power, Maritime Rights Protection and Law Enforcement, Personnel Training, Team Building

\section{Introduction}

The report of the 18th National Congress of the Communist Party of China proposed to "improve the ability of marine resources development, develop marine economy, protect marine ecological environment, resolutely safeguard national marine rights and interests, and build a marine power", which raised China's marine strategy to an unprecedented height. The report states that maritime power is another strategic main line for China's future development and the only way for the Chinese nation to achieve sustainable development and become a world power [1]. In the report of the 19th National Congress of the Communist Party of China, it is clearly required to "adhere to the overall planning of land and sea, and speed up the construction of a maritime power", which has once again sounded the clarion call for the construction of a maritime power [2]. The realization of this important strategic goal is an arduous and complex systematic project, which needs the guarantee of various factors and conditions, in which talents play a leading and decisive role.

China is a coastal country with sea land complex. With its rich resources, convenient channels and Frontier National 
Defense, the ocean is an important strategic fulcrum for the survival and development of the Chinese nation in the $21 \mathrm{st}$ century. Based on historical reasons, in the sea areas under our jurisdiction, islands have been illegally occupied, sea areas have been wantonly carved up, resources have been swallowed and plundered by whales, China's maritime rights and interests have been seriously violated, and the struggle for maritime rights has become increasingly severe and will exist for a long time. It is an important guarantee for the realization of the strategic goal of building a maritime power and a basic requirement for fulfilling the responsibilities of a great power to build a contingent of Chinese maritime rights protection and law enforcement personnel that is commensurate with China's international status and national strategic interests. Personnel training is the key to the construction and development of marine rights protection and law enforcement personnel.

At present, there are still many problems in the construction of marine rights protection and law enforcement personnel team that are not suitable for the needs of the situation and tasks. It has become an urgent task for the construction of China's marine rights protection and law enforcement personnel team to innovate the personnel training mode, strengthen the construction of their own team, and better perform the duties of "rights protection, law enforcement, and service" at sea to meet the needs of the development of the situation.

On the basis of combing the relationship between the strategy of maritime power and personnel training, and the main problems faced by the personnel team of maritime rights protection and law enforcement, this study analyzes the experience and practice of personnel training of maritime power America and China's major neighboring country Japan, in order to put forward countermeasures to strengthen the construction of personnel team of maritime rights protection and law enforcement.

\section{The Relationship Between the Strategy of Maritime Power and Personnel Training}

The strategy of maritime power is a science and technology intensive and talent intensive undertaking. Human resources are important strategic resources, and the first resource and fundamental guarantee for promoting the development of marine undertakings and realizing the long-term goal of building a maritime power [3].

First of all, human resources play a fundamental, strategic and decisive role in economic and social development. Talent is the mainstream leader of economic development. Among the elements of productivity, it is the most core, positive and dynamic one. Other elements can only work through talent. Talents master advanced technology through education and practice, so as to create more production value and determine the direction, speed and quality of economic and social development. Talents are also the winners of international competition. They are related to the rise and fall of a country in the past, today's development priorities and even the future development strategy. The competition in today's world and in the future is fundamentally the competition for talents. The basic national conditions of our country, especially the resource situation, the development level of productive forces and the mode of production, determine that we should pay more attention to the human resources.

Secondly, from the perspective of China's national conditions, the connotation of maritime power with Chinese characteristics includes five aspects: Cognition of ocean, utilization of ocean, ecological ocean, control of ocean and harmonious ocean. Among the five aspects of the marine power strategy, the most fundamental and essential is science and technology and innovation. In the era of scientific and technological revolution, the above-mentioned five aspects of activities are permeated and reflected in the role of science and technology and management talents. Other factors or roles depend on and determine on the core factor of talents, which is dominated and dominated by talents. From the perspective of several basic tasks of maritime power strategy, it shows the role of scientific and technological talents and management talents more specifically and clearly [4]. The content of these tasks is to expand the connotation of maritime power and to make its strategy specific and clear. Similarly, the task of every aspect, in the final analysis, is the problem of talents, especially in today's era, it still depends on the road of talents.

Thirdly, having a high-level talent team is one of the specific indicators and basic characteristics of a maritime power. Starting from the connotation of maritime power, the specific indicators to measure maritime power should be: developed marine economy, advanced marine science and technology, beautiful marine ecological environment, high-level talent team to build and improve marine system, advanced ability to manage marine problems or accidents, and strong maritime defense force. Among them, the talent team is not only the decisive factor in other standards, but also one of the specific rigid and external indicators. In other words, in the specific indicators of maritime power, talents play a key and core role [5]. Without such a talent team, none of the criteria of maritime power can be achieved. Therefore, in the realistic context, to become a maritime power, we must have a team of professional talents with various types and excellent quality.

\section{The Main Problems of Marine Rights Protection and Law Enforcement Personnel}

China's maritime law enforcement personnel are mainly facing the problems of immature team and urgent development.

\subsection{It Is Difficult to Retain Law Enforcement Talents}

From the actual situation of maritime rights protection and law enforcement, the team is younger, and the backbone with rich experience in maritime rights protection and law enforcement is less. Most of them are fresh graduates from 
military academies and new police officers. Due to the late start of maritime rights protection and law enforcement, the relatively few cases, the greater difficulty of cross sea case handling and the longer time of case handling, it takes at least five years to train a backbone of rights protection and law enforcement. However, there is little room for the development of rights protection and law enforcement cadres, and they may also reach a certain position after training. It is difficult to develop further and they have to choose to change jobs, which leads to the loss of rights protection and law enforcement talents.

\subsection{Lack of Professional and Technical Personnel}

The regulations on maritime law enforcement of public security organs issued by the Ministry of public security and put into effect at the end of 2007 endows the maritime police with the power to deal with administrative and criminal cases. The functions of the maritime police are equivalent to those of local public security organs, but they have not had their own forensic, technical investigation and criminal investigation departments. In case of corresponding cases, they need to seek the coordination of local public security organs.

\section{The Main Practice of Cultivating Maritime Law Enforcement Talents in the United States and Japan}

Maritime powers have established maritime rights protection and law enforcement teams, and have accumulated rich experience in maritime rights protection and law enforcement personnel training. China's major neighboring countries have also introduced measures to cultivate talents for maritime rights protection and law enforcement, and are vigorously cultivating talents for maritime rights protection and law enforcement. Learning and understanding the experience and practice of marine rights protection and law enforcement personnel training of major maritime powers and China's major neighboring countries has important reference value for the formulation of China's marine rights protection and law enforcement personnel training strategy. It is also an important way to improve the response capacity of China's marine rights protection and law enforcement departments and strengthen cooperation and exchange.

\section{1. $U S A$}

The U.S. Coast Guard is an active armed force of the U.S. maritime administrative law enforcement. It was established in 1790 and is now under the command of the Department of homeland security. In wartime, it is under the command of the Navy. It has nine divisions, including 41874 active duty personnel, 7057 civilian personnel, 8100 reserve personnel, 30000 auxiliary security personnel [6], 2094 ships and 204 aircraft [7]. Its main tasks include marine safety, maritime safety, natural resources protection, marine traffic management and general defense affairs [8].
There are four main sources of active service officers in the US Coast Guard There are three channels: first, the coast guard College of the United States implements undergraduate education; second, the reserve Academy of military officers mainly recruits college graduates; third, the direct officer training program for pilots, lawyers, engineers, seafarers and other senior professionals; fourth, the undergraduate pre employment program for recruiting sophomores.

There are also three sources for US Coast Guard grass-roots members: first, those who have served in other military organizations, such as land, sea and air force; second, those who have served in the US Coast Guard, which are divided into two types: those who have expired and those who have not; third, those who have not served in military organizations [9].

The personnel training system of coast guard in the United States can be divided into three levels [10]: first, the Coast Guard Academy of the United States, with four-year undergraduate education, trains the backbone personnel of the coast guard; second, six training centers, respectively, train various professionals; third, training teams, providing on-the-job training. The Coast Guard Academy is one of the four federal military academies in the United States. It mainly trains junior officers for the U.S. Coast Guard, as well as international Coast Guard personnel training. The school has five departments, including engineering department, Humanities Department, leadership and management department, mathematics department and science department. It has eight majors, including shipbuilding and marine engineering, civil engineering, mechanical engineering, electronic engineering, operational research and computer analysis, marine environmental science, political science and management. It enrolls about 270 students every year and 20 international students. The total number of students is about 1100 People. The Cadet shall be a second lieutenant with a bachelor's degree in the coast guard. The six training centers are mainly engaged in vocational education and training, with different business focuses. York Town training center is responsible for the training of ship personnel, mainly training the personnel of maritime duty, maritime safety, mechanical equipment and other departments. Petaluma training center is responsible for the training of communication and logistics personnel, mainly training the personnel of information technology department and duty support department, as well as Sergeant training and "C" class boarding and law enforcement personnel training. Cape May training center is responsible for the training of U.S. Coast Guard and reserve recruits, as well as the training of recruits training commanders and recruiters. Chesapeake training quota management center is mainly responsible for training plan formulation, personnel arrangement and other matters. Mobile city flight training center mainly implements daily training for pilots. Elizabeth City flight training center is responsible for the training of flight support technicians. The training team mainly carries out various temporary training and organizes daily military training [11]. 


\subsection{Japan}

Japan's maritime security agency is a Japanese maritime law enforcement agency, which was established in 1948. It is a paramilitary maritime armed law enforcement force with police attributes. It is now under the jurisdiction of the Ministry of land and communications, and under the jurisdiction of the defense agency in wartime. Its main tasks include police rescue, route identification and route identification. Japan's maritime security agency currently has 13208 personnel, 449 boats, 73 fixed wing aircraft and helicopters, which belong to the headquarters of the agency and 11 administrative areas. Japan's maritime security officer training is mainly undertaken by the maritime security university and the maritime security school. The University of maritime security provides four different levels of education, including undergraduate education, specialty education, specialty education and research education. Among them, undergraduate education is a four-year degree education, which is the main body of the school's education. It has three majors, namely navigation, mechanical and electrical engineering, and communication. It enrolls about 70 young people under the age of 21 who graduated from high school every year. During the school period, they learn the knowledge and skills needed to carry out maritime security tasks, and graduate with a bachelor's degree. After graduation, the students will be transferred to specialized education for six months, mainly for professional knowledge learning and global ocean navigation practice. The one-year length of special education is "training of higher level maritime qualification and corresponding various special qualifications" for the general occupation of maritime security agency The training section mainly provides language learning, diving training, environmental analysis and core cadre training for the staff of the maritime security department. The training lasts about 50 days [12]. Maritime security school is a secondary school for training general staff. It mainly provides professional and skill training for in-service maritime security officers, newly recruited excellent vocational schools, short-term universities and university graduates. It has four majors, namely shipping, aviation, information system and marine science. The length of schooling is 1-2 years. The maritime security school has two branches: MENSI branch and Miyagi branch. MENSI branch mainly provides on-the-job training for boat personnel, while Miyagi branch is mainly responsible for the training of aviation personnel, such as helicopter pilots and mechanics. It is worth mentioning that Japan's maritime security agency also has a maritime special police team composed of 56 people, which is divided into seven special police teams with 8 people in each team [13]. At the beginning of its establishment, the team hired us military instructors to be responsible for training, and now it has formed its own instructor team. Its training subjects are in accordance with the "seals of US Navy special forces" The implementation of the training program is mainly responsible for "the protection of ships carrying nuclear waste, the detection of unidentified ship cases, the inspection of nuclear proliferation prevention, the suppression of riots on ships, the fight against piracy, the protection of overseas Japanese citizens, the fight against maritime drug transport and the fight against illegal immigration." [14]

\section{Suggestions on the Construction of Marine Rights Protection and Law Enforcement Personnel}

\subsection{Strive to Build a Complete Training System of Marine Rights Protection and Law Enforcement Talents with "Academic Education + Professional Education"}

The U.S. Coast Guard is the most powerful maritime law enforcement force in the world, and the Japanese maritime security agency is the most powerful maritime law enforcement force in Asia. Due to the large number of posts, they have established a complete "academic education + professional education" maritime police personnel training system. Among them, there is one academic education institution and six professional education institutions in the United States, and one academic education institution and one professional education institution in Japan (actually three, because there are two branches). Each of them is responsible for the implementation of classified education and training.

In addition, the implementation of vocational education and vocational training for maritime rights protection and law enforcement personnel is an indispensable part of the maritime police personnel training system in various countries. All countries carry out professional education and training for maritime rights protection and law enforcement personnel, but not necessarily through the implementation of academic education to cultivate maritime rights protection and law enforcement personnel. However, in the countries that implement diploma education, the scale of diploma education is not large. For example, the United States only recruits about 270 people every year, while Japan only recruits about 70 people. It is not difficult to see that in the personnel training system of maritime rights protection and law enforcement, professional education is the main body, which is mainly determined by the professional particularity of maritime rights protection and law enforcement personnel [15].

\subsection{Attach Great Importance to the Cultivation of Practical Ability of Maritime Rights Protection and Law Enforcement Personnel}

With the help of ships and aircraft and other carriers, the basic qualities of maritime law enforcement personnel are to be familiar with the operation and maintenance of ships and aircraft, to be proficient in various maritime law enforcement businesses, to master international and domestic marine related laws, to have military skills in law enforcement and emergency handling, and to have the ability of foreign exchange. Therefore, from the perspective of talent types, maritime law enforcement personnel should have the following basic qualities Foreign law enforcement personnel 
are typical applied talents. In the aspect of practical ability training of maritime rights protection and law enforcement personnel, the United States and Japan have taken the most prominent measures. The Coast Guard Academy of the United States has formulated the "summer training program for students", which mainly uses the summer vacation time to go to the coast guard station, cutter, eagle and sector for about 40 weeks of practical training, including 22 weeks for sophomores and 18 weeks for seniors [16]. The U.S. Coast Guard is equipped with a 1780 ton Eagle training ship. Every summer, it organizes students to sail around the world to improve their sailing skills. In the undergraduate education stage, Japan has set up 22 weeks of practical teaching time, including search and rescue training, shooting training, pursuit training, helicopter landing (departure) training and other subjects, of which 8 weeks is a week around Japan. During the period of specialized subject education, Japan arranged trainees to go to the ocean going training ship "Kojima" for a 15 week round the world navigation training. In addition, the Japanese maritime security agency holds annual review and comprehensive exercises in the Tokyo Bay every May.

\subsection{Make Full Use of the Human Resources of the Army, Police and the People}

Generally speaking, it can be divided into four situations. One is to establish their own academic education institutions for training. In the United States and Japan, undergraduate education is implemented from high school graduates or freshmen and sophomores. For example, the United States only recruits about 270 people a year, while Japan only recruits 70. Its purpose is to build the core strength of maritime rights protection and law enforcement team through elite education. The second is the selection of military active and retired personnel and graduates from military academies. This approach is mainly adopted by countries that have newly established maritime law enforcement forces. Based on the needs of maritime armed law enforcement, military training, especially with the background of naval training, is more competent for maritime law enforcement. The third is to select police officers and graduates from police academies. Directly select the police and graduates of the police academy, or entrust the police academy to train them. Fourth, local university graduates and professionals should be selected.

\subsection{Deepening Exchanges and Cooperation to Cultivate Talents with International Vision}

We should strengthen exchanges and cooperation between countries in the training of maritime rights protection and law enforcement personnel, and cultivate maritime police personnel with international vision. Because the objects of maritime rights enforcement are mostly foreign ships and personnel, maritime criminal activities often have international characteristics, and maritime rescue and humanitarian rescue often need international cooperation, all countries attach great importance to improving the international vision of maritime rights enforcement personnel through exchanges and cooperation. In this regard, there are two main ways for the United States: one is to recruit 20 international students from all over the world through the Coast Guard Academy of the United States, and at the same time, send their students to other countries to study; the other is to invite students from other countries to participate in the round the world voyage of the eagle training ship. Japan Maritime Security University also accepted international students, and invited coast police personnel from other countries to participate in the round the world voyage of Kojima. Japan Maritime Security University regularly holds exchange meetings, student days and debate competitions among students of maritime security universities (schools) in Southeast Asia and the Pacific region every year. The purpose is to understand the maritime rights protection and law enforcement business and personnel training situation of other countries through exchange activities, so as to improve the international vision of students.

\section{Conclusion}

Marine rights protection and law enforcement personnel are the main actors in the practice of maritime rights protection and law enforcement, and the quality of personnel training is directly related to China's maritime rights protection and law enforcement ability and response level. It is an important guarantee for the realization of the strategic goal of building a maritime power and a basic requirement for fulfilling the responsibilities of a great power to build a contingent of Chinese maritime rights protection and law enforcement personnel that is commensurate with China's international status and national strategic interests. Through the analysis of the measures taken by the United States and Japan in the cultivation of maritime rights protection and law enforcement personnel, this paper concludes that the differences in the areas under their jurisdiction, the functions and tasks of maritime rights protection and law enforcement personnel, and the situations and tasks faced by maritime rights protection and law enforcement personnel are the main reasons for the different strategies of maritime rights protection and law enforcement personnel cultivation in various countries. However, there are some common rules in personnel training, so this paper summarizes the following four aspects to strengthen the construction of marine rights protection and law enforcement personnel in China. They are: 1) Strive to Build a Complete Training System of Marine Rights Protection and Law Enforcement Talents with "Academic Education + Professional Education"; 2) Attach Great Importance to the Cultivation of Practical Ability of Maritime Rights Protection and Law Enforcement Personnel; 3) Make Full Use of the Human Resources of the Army, Police and the People; 4) Deepening Exchanges and Cooperation to Cultivate Talents with International Vision. For quite a long time in the future, China's maritime rights protection and law enforcement task will be more arduous. It is necessary to build a team of Chinese maritime rights protection and law enforcement personnel that is commensurate with China's 
international status and national strategic interests. How to scientifically cultivate maritime rights protection and law enforcement personnel urgently needs strategic planning. One of the ways is to learn from the experience and practice of other countries, but at the same time, we should take full account of China's national conditions and formulate a marine talent training strategy with Chinese characteristics.

\section{References}

[1] The drafting group of the report documents of the 18th National Congress of the Communist Party of China. Compilation of the report documents of the 18th National Congress of the Communist Party of China. Beijing: People's publishing house, 2012.

[2] Report document drafting group of the 19th National Congress of the Communist Party of China. Compilation of report documents of the 19th National Congress of the Communist Party of China. Beijing: People's publishing house, 2017.

[3] Wang Zan, Zhao Wei \& Wang Fang. (2019). Optimization of legal personnel training mode under the strategy of maritime power -- from the perspective of maritime law enforcement personnel training. China Maritime Law Research (03), 67-76.

[4] Shan Juan. (2019). Construction of personnel training system of marine law major under the strategy of "maritime power". China Adult Education (10), 51-54.

[5] Liu Bing \& Sun fabo. (2018). Maritime power strategy and legal education reform: Exploration and practice of marine legal personnel training in coastal local universities. Research on Legal Education (04), 111-128.

[6] Department of Homeland Security. Budget-in Brief Fiscal Year 2010 U.S. Department of Homeland Security. February 2009: 81.
[7] Bian Ziguang. (2012). Maritime law enforcement systems of various countries (Volume II). Taiwan: sauway Information Technology Co., Ltd.: 15, 23, 34, 33.

[8] Wu Fan \& Yang Bo. (2020). A comparative study on the operational principles of Maritime Law Enforcement between the Chinese coast guard and the US Coast Guard. Journal of the Armed Police College (11), 45-53.

[9] Zheng Zhong. (2016). Strategic analysis and Enlightenment of maritime police personnel training in the United States, Japan and other seven countries. Journal of maritime police college of public security (03), 42-48.

[10] Li Jie \& Li Lei. (2020). The reasons and Enlightenment of the efficient law enforcement and service of the US Coast Guard. Journal of the maritime police college of Public Security (04), $75-80$.

[11] Li Jia. (2020). Analysis and Enlightenment of the operation mode of the U.S. Coast Guard. Journal of the maritime police college of Public Security (02), 13-20 + 28 .

[12] Li Ming. (2019). A preliminary study on the education system of Japan Maritime Security School. Journal of Jiangsu Police Academy (01), 122-128.

[13] Zhao Xuhui. (2016). The Enlightenment of the establishment, function allocation and education and training of Japanese coast guard. Public Security Education (05), 76-78.

[14] Li Ming. (2010). Weapon equipment and combat training of Japanese maritime special police. Police (2), 107.

[15] Zhang Ke. (2017). Reflections on the cultivation of marine talents in the new era. Innovation and Technology (01), 53-55.

[16] U.S. Coast Guard Academy Commandant of Cadets. Cadet Summer Training Manual. U.S. Coast Guard Academy, 2011: 2-4, 2-11, 2-17, 3-3, 3-5. 